DOI: $\square$ https://doi.org/10.15407/techned2020.03.030

\title{
ENERGY EFFICIENT STRATEGIES OF POWER ACTIVE FILTRATION BASED ON OPTIMAL DECOMPOSITIONS OF LOAD CURRENTS AND CORRESPONDING POWER LOSSES
}

Journal

Publisher

ISSN

Issue

Pages
Tekhnichna elektrodynamika

Institute of Electrodynamics National Academy of Science of Ukraine 1607-7970 (print), 2218-1903 (online)

No 3, 2020 (May/June)

$30-35$

\section{Authors}

M.Yu. Artemenko ${ }^{1 \star}$, Y.V. Kutafin ${ }^{1 \star \star}$, V.M. Mikhalsky ${ }^{2 \star \star \star}$, S.Y. Polishchuk ${ }^{2 \star \star \star}$, V.V. Chopyk

\section{I.A. Shapoval}

2

1- National Technical University of Ukraine I. Sikorsky Kyiv Polytechnic Institute,

Peremohy ave., 37, Kyiv, 03056, Ukraine

2. Institute of Electrodynamics of the National Academy of Sciences of Ukraine,

Peremohy ave., 56, Kyiv, 03057, Ukraine,

e-mail: mikhalsky@ied.org.ua

* ORCID ID : https://orcid.org/0000-0001-9341-9238

** ORCID ID : https://orcid.org/0000-0002-8156-1277

*** ORCID ID : https://orcid.org/0000-0002-8251-3111

**** ORCID ID : https://orcid.org/0000-0002-6978-2747

***** ORCID ID : https://orcid.org/0000-0002-5046-5223

****** ORCID ID : https://orcid.org/0000-0002-9107-5061

\section{Abstract}

Optimal decompositions of load current vectors and the corresponding instantaneous and integral power losses of multiphase power supply systems based on the equations for determining the active current taking into account the ratio of resistive parameters in the transmission line are justified. The minimum values of instantaneous and integral power losses associated with the transfer of energy with a given value of active power are determined. Based 
on the optimal decomposition of the load current vectors, four control strategies for the shunt active filter are constructed each of which provides an extreme value to one of the quality parameters. References 13.

Key words: shunt active filter, active current, power loss, power factor.

Received: 28.02.2020

Published: 05.05.2020

\section{References}

1. Fryze S. Moc czynna, bierna i pozorna ukladu 3-fazowego o odksztalconych przebiegach napiec fazowych i pradów przewodowych. Wybrane zagadnienia teoretycznych podstaw elektrotechniki. Warszawa-Wroclaw: PWN. 1966. Pp. 250-256.

2. Akagi H., Watanable E.H., Aredes M. Instantaneous power theory and applications to power conditioning. Piscataway: Wiley -IEEE Press, 2017. 472 p. DOI: https://doi.org/10.1002/978111 9307181

3. Czarnecki L.S. Currents' Physical Components (CPC) concept: a fundamental of Power Theory. Przeglad Elektrotechniczny. 2008. Vol. 84. No 6. Pp. 28-37.

4. Garcesa A., Molinas M., Rodriguez P. A generalized compensation theory for active filters based on mathematical optimization in ABC frame. Electric Power Systems Research. 2012. Vol. 90. Pp. 1-10. DOI:

https://doi.org/10.1016/j.epsr.2012.03.011

5. Herrera R. S., Salmerén P., Vázquez J. R., Litrán S. P., Pérez A. Generalized instantaneous reactive power theory in poly-phase power systems. Proceedings of 13th European Conference on Power Electronics and Application

(EPE'2009). Spain, Barselona, September 8-10, 2009. Pp. 1-10.

6. Kim $\mathrm{H}$., Akagi $\mathrm{H}$. The instantaneous power theory on the rotating $\mathrm{p}-\mathrm{q}-\mathrm{r}$ reference frames. IEE E International Conference on Power Electronics and Drive Systems

(PEDS'99). Hong Kong. July, 1999. Pp. 422-427. DOI:

https://doi.org/10.1109/PEDS.1999.794600

7. Montano J.C., Salmeron P., Thomas J.P. Analysis of power losses for instantaneous compensation of three-phase four-wire systems. IEEE Transaction on Power Electronscs. 2005. Vol. 20. No 4. Pp. 901-907. DOI:

https://doi.org/10.1109/TPEL.2005.850956

8. Peng F.Z., Lai J.S. Generalized instantaneous reactive power theory of three-phase power systems. IEEE Transactions on Instrumentation and Measurement. 1996. Vol. 45. No 1. Pp. 
293-297. DOI:

https://doi.or

$\mathrm{g} / 10.1109 / 19.481350$

9. Tugay D., Zhemerov G., Korneliuk I., Shkurpela A. Parallel power active filter new control technique based on modified p-q-r power theory. Visnyk Natsionalnoho Tekhnicnoho Universutetu Kharkivskyi Politekhnichnyi Instytut

. Serija: Elektrychni mashiny ta elektromekhanichne peretvorennia energii. 2019. No 20 (1345). P. 173-181. DOI:

https://doi.org/10.20998/2409-9295.2019.20.22

(Ukr)

10. Artemenko M.Yu., Mykhalskyi V.M., Polishchuk S.Y. Definition of apparent power of three-phase power supply systems as a theoretical basis for development of energy-efficient shunt active filters. Tekhnichna Elektrodynamika. 2017. No. 2. Pp. 25 -34. DOI: https://doi.org/ 10.15407/techned2017.02.025

(Ukr)

11. Artemenko M., Batrak L. and Polishchuk S. New definition formulas for apparent power and active current of three-phase power system. Przeglad Elektrotechniczny. 2019. No 8. Pp.

81-85. DOI:

. org/10.15199/48.2019.08.20

https://doi

12. Artemenko M.Yu., Batrak L.M., Polishchuk S.Y., Mykhalskyi V.M., Shapoval I.A. The Effect of Load Power Factor on the Efficiency of Three-Phase Four-Wire Power System with Shunt Active Filter. Proceedings of IEEE 36th International Conference on Electronics and Nanotechnology

2016. Pp. 277-282. DOI:

(ELNANO 2016). Ukraine, Kyiv, April 19-21, ELNANO.2016.7493067

https://doi.org/10.1109/

13. Artemenko M.Yu., Kutafin Y.V., Mykhalskyi V.M., Polishchuk S.Y., Chopyk V.V., Shapoval I.A. Instantaneous power theory of polyphase power systems with regard of transmission line resistive parameters. Tekhnichna Elektrodynamika. 2019. No 4. Pp. 12-22. DOI: https://doi.org /10.15407/techned2019.04.012

(Ukr) 


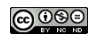

This work is licensed under a Creative Commons Attribution-NonCommercial-NoDerivatives 4.0 International License 